HStud 24 (2010)2, 169-179

DOI: 10.1556/HStud.24.2010.2.1

\title{
CARTOGRAPHY AS A TOOL OF NATION-BUILDING IN HUNGARY AND MEANS OF LEGITIMIZING HUNGARIAN ETHNIC BORDERS AND SPACES
}

\author{
RÓBERT KEMÉNYFI \\ University of Debrecen, Debrecen \\ Hungary
}

\begin{abstract}
This paper focuses on the set of ideological means and systems of scholarly argumentation presented by the field of geographical science between the two world wars in an attempt to prove the unity of the Hungarian national space and demonstrate the impracticability of the spatial confines within which the state had to exist due to the ruling implemented after the Paris Peace Treaty. Specifically, I will elaborate on the geographical myths used to legitimize the so-called Hungarian state space, with special attention devoted to ethnic mapping as an ethno-political device and means of articulating discourses of power discourse.
\end{abstract}

Keywords: map, space, myth, nation-building, spatial-turn, ethnic boundaries

It is perhaps not by chance that geography, or "the science of space," is now included in academic discussions of the processes of nation-building. This may be simply because in order for the field of history to be able to interpret the nuances of potential approaches to the rather complex relationship between society and space or spatiality, it is necessary to implement the viewpoints offered by other disciplines as well.

At the end of the 19th century geography on the one hand found its appropriate place among sciences and scholarly disciplines and, on the other hand, managed to clarify its proper subject matter. A central concern became the detailed analysis of the natural environment that surrounds humankind as well as the (external) environment that human beings themselves shape and transform around themselves, along with the interpretation of spatial correlations. In other words, in the scholarly/scientific philosophy related to geography, the concept of space appeared as the uniform basic issue of the discipline of geography. According to Karl Ritter, however, space is not empty, but "filled with objects," which means that this concept is based on the absolute theory of space. However, the view of space as an "objective container" became more and more diversified in the second half of the past century, and spatial concepts and spatial theories appeared in the process of what could be assessed as a "spatial turn" in scholarly-scientific thinking, which tended to regard space increasingly as one of the projections of social processes. 
As the appearance of "soft" spatial concepts facilitated the approach of geography (a discipline that moves essentially in the synchronic time frame) towards the application of the achievements and methods of social sciences and the recognition of the diachronic aspect, the field of history, which is basically vertical in its treatment of time, was equally forced to move closer to spatial philosophical thinking and social geography by the declaration and acceptance of spatial synchronicities and parallel worlds (see Soja, 1989). This is exactly why, as a matter of course, geography uses archives and various records of drafts and censuses (among other things), as the historical spatial processes can be interpreted correctly only with the help of these sources, just as these sources may also provide logical and scholarly explanations for the phenomena of natural geography. This means that the historical viewpoint (and sources) can enrich and simultaneously highlight the approach of geography by adding an additional aspect that has proved to be a basic concern of geography, which is temporaneity.

After all, we all know for a fact that time is the concern of cartographers. The human branch of classical geography focused primarily on the external, environmental (spatial) relations of human presence, the order of social activities and of the population itself as shaped in the (absolute) space through historical development, and it used to concentrate pointedly on the present, even if it used historical data as well. Conversely, present-day geography has ("at last") turned this relationship upside down. It does not anymore discuss temporal processes from the aspect of space, but rather addresses spatial structures that are formed on the basis of historical processes. This path seems to be appropriate for the purpose of approaching mythical ideas in geography with due criticism and for providing reasonable explanations for the origin of natural forms "created by supernatural powers." It is in this context, i.e., by considering the time horizon, that we need to approach the former (and sometimes also even the present) ideological constructions of Hungarian geography, constructions with which it has interpreted the spatial imprint of the (national/ethnic) presence of Hungarians in the Carpathian Ba$\sin$. This seems to be all the more the case, given that a deeply rooted feature in Hungarian geography and even scholarship in general is the declaration of how Hungarians are bound to their natural environment and landscape, which finds expression in the principle of "a history and culture that could happen only here and only in this way." The interpretation of this basic principle, i.e., that of the triad of place, historical time, and natural environment may move towards the establishment of creation myths. The forced amalgamation or confusion of empirical or historical time and the huge time periods of natural processes (e.g., geological formations) can only result in the acceptance of the tenet of "created space." Thus according to this way of thinking, the events that create our geographical environment necessarily determined our historical processes and gave our (national) spatial structures the form they have today. 
For easily understandable reasons, Hungarian geography between the two world wars put special emphasis on the efforts to explain the questions surrounding the issues of landscape, space, and nation and the close-knit (or even fateful) relationship that developed between them in the wake of the shocking decision made at the Paris Peace Treaty. This should not be surprising, however, as it has been recognized for some time in contemporary social research, due to the work of Pierre Nora and Alieda Assmann, that the most original, most ancient, and most important part in national cultural memory is played by space (Nora, 1990; Assmann, 2003).

Entire landscapes can become the medium of cultural memory and may be filled with semiotic content. As a consequence, the conscious acts of the local population to harmonize the given part of space with certain mythic notions have been very important in the process of strengthening their ethnic/national identity in the past as well as the present (Gribben, 1990, 277-91).

Veikko Anttonen, interpreting the term "sacral," has analyzed the connection between space and religion and, with the help of this viewpoint, indirectly discussed the so-called "sacred" functioning of national spaces. Anttonen contends that individual communities mark the special points of the area they use as early as the time of their settlement of the given area. These include natural places (such as rivers, lakes, or hills) that separate their own space from the (wilderness) areas of the "other" group(s) of people. In Finnish culture, the basically adjectival term "pyhä" (meaning "separate" or "highlighted from the environment") expresses the significance of such locations, the significance of spatial points as borders and boundaries between peoples, the crossing of which is considered to be of magical or religious nature. Transgressing these borders is only possible after the appropriate, i.e., socially prescribed, rituals. The decoding of the meaning of these sacral borders or boundaries is possible only for those who belong to the given communities (Anttonen, 1999, 9-22).

In this context the reasons for the existence of the Hungarian political/national space area theory can be understood as a part of historical geography, as the range of the Carpathian Mountains and the area surrounded by it never constituted merely simple geographical frames, but always had a distinctive role for Hungarians.

The notion of the thousand-year-old country of Saint Stephen as a "Sacral Unity" became especially strong after 1920 (see Zeidler, 2001, 2002). This meant that in scholarly life in Hungary not only Ratzel's principle of "nature created Hungary through the complete organic correlation as a unified life province" held sway, but also the idea of how "something more" or "some Larger Power" assisted in creating the natural (sacral) space of the Hungarian nation. Thus, in the last decade of the 19th century and in the first few decades of the 20th an aspiration took root in Hungarian scholarly circles to proclaim the idea of a unified na- 
tional and state space, very similar to the notion of an organic, unified national history and folk culture.

It was precisely this "nature-given created state space" that the government feared, as early as the turn of the 19th and the 20th centuries, was endangered by the ethnic minorities living in Hungary, which is why the government paid increasingly close attention to the spatial situation and spatial movements of non-Hungarians and their "space-occupying power," which was seen as a force that might drive back Hungarians. The best scholarly/scientific tool for monitoring these processes was what is referred to as the ethnic map.

The history of ethnic cartography contains reports of a number of newly created ethnic maps dating from the first half of the 20th century that deploy increasingly refined methods of delineation. We know for a fact, as noted by Pál Teleki, that it was expressly out of political interests that ethnic maps were produced for the peace treaties that brought an official end to World War I. According to semiotics, maps are icons or pictorial sign(al)s that bear some sort of resemblance to their subjects. However, the universal codification of maps also results in an inevitable simplification of reality and, thus, given their inherent abstraction, maps cannot be seen as anything more than conceptual models. Yet the intensive generalization highlights only those features of macro-level ethnic processes displayed in maps of small scale relations (based on single-word statistical responses) that provide a superficial, if perhaps spectacular impression of the most basic ethnic components (structure) of a given area.

Due precisely to this quality, the history of the establishment of modern European nation states demonstrates that the ethnic/linguistic maps and statistics were either made on the basis of ideological considerations in the first place or they represented/represent a possibility for exploitation according to the current (nation state) political interests.

In one of his treatises, Pál Teleki himself acknowledges that, for all the most painstaking scholarly efforts put into the project, it is simply impossible to produce a "politically neutral" ethnic map in the middle of Europe that would be acceptable for all, since it is exactly the non-correspondence of the individual ethnic and state boundaries that causes the basic antagonistic conflicts between the peoples of this region (Teleki, 1937, 60-70). In Hungarian cartographic practice, the above attribute ("spectacular") refers to optical and psychological effects that are not featured as the subject matter of individual studies but represent parts and parcels of a tacit agreement legitimized by the history of the science of ethnic cartography: namely, the legend and colors used in the maps. The various charts, diagrams, and other means of representation (including circles, balloons, cubes, and columns) may lead the non-specialist viewer of a map astray when assessing degrees of magnitude. Even colors can exert an irrational and/or emotional influence on people that may result in totally differing perceptions or overall impressions 
concerning the size of areas occupied by individual ethnic groups or their mere "capacity to occupy certain areas." Cartographers have a way of determining where the colors should be tense, where they should attract or concentrate attention, or even where they should decrease the interest or the intentness of the viewer. Apart from the central use of red or gules, the application of colors in ethnic maps can only be interpreted in relation to that central color of red. Cartographers have made, and continue to make, their decisions concerning the representation of individual coloring codes in maps primarily on the basis of the color effects as related to the color red.

Imre Jakabffy (1915-2006), along with Pál Teleki and András Rónai (1906-91) one of the editors and producers of ethnic maps in the third and fourth decades of the twentieth century, revealed to me in an interview once that the color red was predominantly used in the above fashion, i.e., for demonstrating the "area-occupying" power of one's own ethnicity:

Red is an attractive color. The color red has a magnifying effect. If that happens to be the case, let us then make it our single effect and concept that we appropriate red for ourselves. [This is] because no matter who produces an ethnographical map, he or she will invariably reserve red for his or her own ethnicity. If it is a Slovakian [cartographer], the Slovakians will be marked with red. [...] Red is, so to speak, a color that irritates your neighbors. [...] The color red produces an explosion. This is why your own nation is always red (Interview with Imre Jakabffy, December 27th, 2004).

The other method, employed less frequently, is when the color red marks an ethnicity that "endangers," "threatens" or "intrudes into" one's own territory. These latter, usually large-scale maps are normally prepared for detailed micro-examinations of settlements of disputed affiliation along ethnic borderlines. A plastic example for this sort of coloring would be the map bearing the title $\mathrm{A} \mathrm{ma}$ gyar-szlovák nyelvhatár vidékének ... [... of the Area of the Hungarian-Slovak Language Boundary], published in 1942 by Államtudományi Intézet [Institute of Political Sciences; verbatim: State Studies Institute]. In this map, the Slovak ethnic territory is marked with the color red (see the exposition of colors in Keményfi, 2007, 55-65). Although ethnic maps apply all of the various contrastive effects simultaneously, the population density map of Pál Teleki is of particular interest from the perspective of color choice. What we can observe in this map is the joint effect of quality and quantity of light and shade contrasts and the resulting pervasive energy of red. It is not by chance that this map of population density by Teleki is oftentimes unofficially dubbed the "Carte rouge" because of the striking dominance of the color red. ${ }^{1}$ This map seems to achieve its most conspicuous effect through what is not really its primary objective. With scholarly 
precision, Teleki uses red ("Hungarian") only to indicate the territories where the level of population density would demand it, thus embedding these ethnic Hungarian areas in narrower or broader white frames of unpopulated sections, a technique giving the impression that the larger red blocks seem to be moving forward towards us in space from the otherwise flat plane of the sheet.

In my view, ethnic maps do not essentially belong within the scope of academically strict cartographic scholarship. To use a concept coined by the Austrian social scientist and theoretician Otto Neurath, ethnic cartography is but a "method of pictorial statistics." It is a method of presentation "which we want to use when the pictorial demonstration for introducing our concept or ideology promises a lot more than words do" (Neurath, 1991, 423). A further characteristic feature of maps is that they provide a key or legend to the universally standardized codes. The cartographers are supposed to tell us what the shades, colors, and contours indicate, or what surface objects they represent. Thus, the interpretive processes of the makers of maps must correspond somehow to the interpretive processes of viewers (Gombrich, 2003, 98-100).

The branch of presenting cartographic practice according to Otto Neurath's school of picture education urges that, in the process of education, the universally valid codes used in maps should be introduced as early as possible. This is also assisted, for example, by the explicit and unambiguous color code, used consistently already in the early phases of education. As an example, he gives the green color of the Arab world, which immediately (as an acquired skill) facilitates the identification of the character of the given territory on the map. Ethnic maps in the efforts related to the nation-state status of Central European peoples have become "graphic icons" or symbols of national and territorial unity. Following in the footsteps of Umberto Eco, we could also say that we normally compare 'stored images" with data perceived at any given point in time. A correspondence between the two operates the iconic code, which triggers the process through which we can get to the level of proper recognition and identification, in our case of the map (Eco, 1976, 191-217).

In my view the ethnic map sequences prepared by the so-called civilized nations of Central Europe depend heavily on the specific situations in which they appear. In other words, we have to take into consideration the concrete medium in which they figure. Ethnic maps of the more comprehensive type, which cover larger individual areas, play a part in symbolic political/ethnic conflicts even today. One needs only think of the public administration transformation processes that have taken place in these countries. The question of where and how these maps are actually used should then be analyzed separately from this perspective. As a practicing ethnographer in the course of fieldwork, I have repeatedly stumbled across recently prepared Hungarian ethnic maps in the cultural venues or mayors' offices (where they are generally kept "sub rosa" and rolled up, but still 
turn up every now and then) of small Hungarian villages of the region called Felvidék (present-day southern Slovakia).

A Hungarian cartographer producing ethnic maps has also told me that, in a number of cases, these maps were ordered explicitly by minority political organizations, and it was the "commissioner" who decided, for example, what color code to apply. Yet this is no secret at all, as the website of MTA Földrajzi Kutatóintézet [Geographical Research Institute of the Hungarian Academy of Sciences] even lists the ethnic cartographical research projects supported directly by government and minority organizations (see http://www.mtafki.hu/projekt_tf.htm).

In other words, ethnic maps are the pictorial channels of symbolic ethnic conflicts, the instruments of pictorial dialogues or map-like coded messages between ethnicities, which sometimes have only symbolic and other times real and even grave consequences. Mostly, they represent a message either to the neighboring peoples or to the European political decision-makers and, of course, a message to the ethnic groups themselves (in this case the Hungarians) about their numbers and circumstances in the given regions. As an example of this "dialogue," let me cite a brochure written in German for international audiences edited by Imre Jakabffy and published in 1942 in order to refute the fabrications contained in Romanian ethnic maps. Once we get a chance to look into this publication, it becomes quite clear that a considerable amount of energy was put into the effort of adjusting or refuting the Romanian ethnic maps (Jakabffy, 1942). (Why does cartographic practice elicit such heated responses or move such a great extent of methodological apparatuses?) It is surely not by chance, then, that cartographer Ute Schneider mentions the power of maps in the title of a recently published volume (Schneider, 2004).

Furthermore, it might not sound too far-fetched on my part to suggest that, on the basis of military literature, it is quite apparent on the basis of how they operate (as special techniques) that ethnic maps also have their proper niche in the system of psychological warfare (Watson, 1985, 364-77).

Apart from the most imposing and widespread ethnic maps, Hungarian scholarship has also presented a mythic system of arguments (that could be illustrated with the following list of examples) for the purpose of proclaiming the magnitude and unity of the Hungarian national space.

1. In the 1920s, geographer Gyula Prinz came up with the so-called Tisia Theory. According to Prinz, the ancient crystalline block that had sunk to the bottom of the Alföld [Great Plains] is of a homogeneous structure, and the range of the Carpathian Mountains then was rolled up on and around this block as if on a (boot)last. Prinz reckoned that this uniform bedrock base also demarcated a unified state space. This means that Hungary, the state is nothing less than the "impact" of nature; consequently, only this state space can function or operate effectively in the Carpathian Basin (Figure 1). 


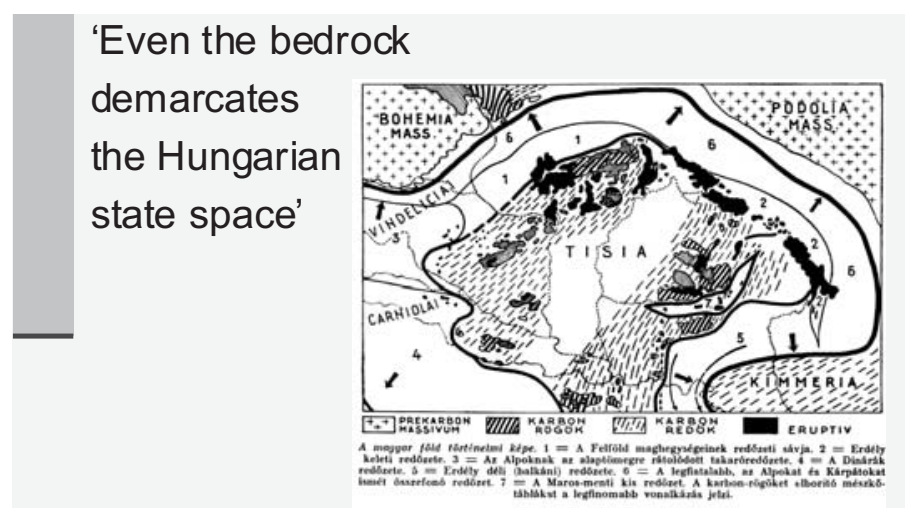

Figure 1. The Tisia Block Myth

2. Prinz is responsible for the notion of "Magyar Mezopotámia" [Hungarian Mesopotamia], as well. The natural basis for this idea is that Hungarian culture developed on the surface of an alluvial plain. This sort of natural environment was the precondition of great civilizations based on agriculture. In other words, the intrinsic Duna-Tisza [Danubius-Tibiscus] river structure, which is similar to that of the rivers Tigris and Euphrates, would elevate Hungary to the status of a Mesopotamian country (Figure 2). This is how the central Hungarian area could become the distributing core of culture and how this culture could be radiated towards the neighboring peoples, who also lived together with us in the Carpathian Basin. Our "cultural power" therefore "elevated" the cultural level of the other peoples who lived with us on the edges of the Carpathian Basin. Accordingly, the end or the borderline of the highbrow "core culture" is located where the territory populated by Hungarians ends, or where the plains shift into the Carpathian Mountains.

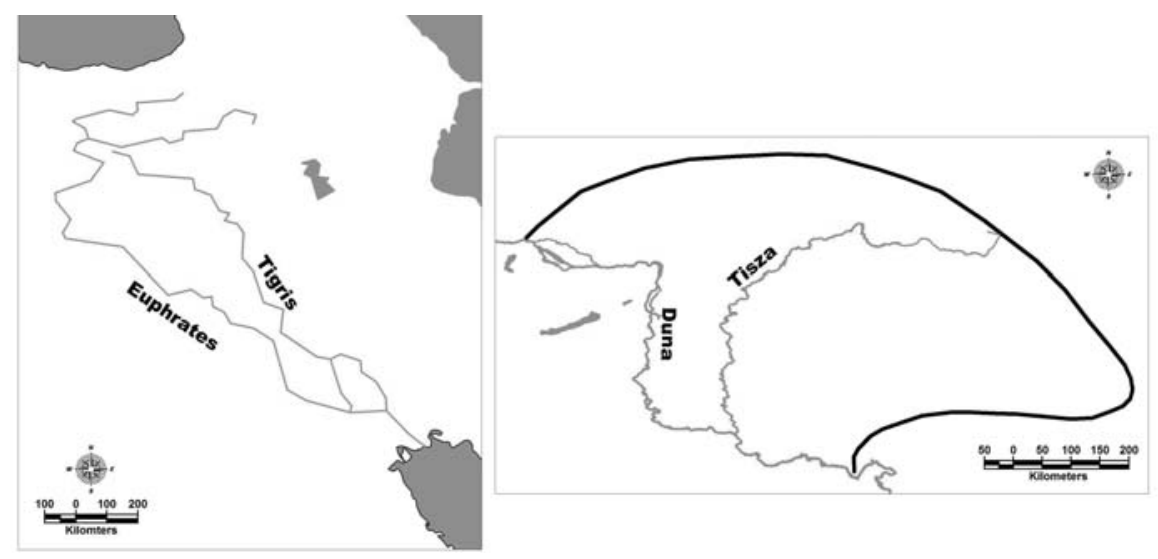

Figure 2. "Hungarian Mesopotamia" 
3. The concept of ethnic/national landscape propounded and emphasized by Teleki is also worthy of mention in this context. The essential idea in it is that an ethnic landscape is "egy-egy nemzetiség tipikusan a saját etnikai jellegzetességeiben felismerhető tájformáló erő által alakított térfelszín" [the space surface formed by a landscape-forming power recognizable in the typical ethnic features of individual nations]. The term that entered the Hungarian language from the relevant German literature assumed the ethnic quality to be a primary space-surface-forming force, as opposed to a simple way of life. Obviously, this piece of specific terminology, already refuted and discredited by current representatives of geography, was supposed to justify the historical continuity of the given group of people related to a concrete part of the landscape.

4. The notion of sacred/sacral landscape (szent táj), received with some degree of skepticism even by contemporary (first half of the 20th century) representatives in the field of the ethnography of religion, also belongs here. Their disbelief stemmed from their view that the definition of sacral landscape ignored the complexity of landscape.

5. The man who coined the term, the German Georg Schreiber, also included in the original definition the German life-force as that of a "gigantic great-family." He opined that there was a close connection between the "people" (Volkstum) and the "sacred quality." He believed that the relationship between religiousness and the people could be best recognized in sacral landscapes. In other words, it was its deep religiousness that had helped the German people (and protected them against other peoples) in their effort to preserve their life force and high level of culture and civilization and leave the impression of this culture in the landscape (Bausinger, 1965, 177-204). In Hungarian circles of geography, this notion took the form of the following characteristic sentence: "A katolicizmus a nyugatias lelkiséget biztosítja a magyarság számára, kiélezi a magyar műveltségi életteret" [Catholicism ensures the western spirituality for Hungarians; it puts an edge to the Hungarian educational life-space] (Prinz, 1942, 129).

6. The last item in this list, admittedly abbreviated in the interests of concision and brevity, could be the idea of államhatár-tartósság [state border continuity], developed to a level or remarkable subtlety by András Rónai. On the basis of the mythic principle according to which "time legitimizes," Rónai handles the Carpathian Basin as a natural state space unit, which is un-detachable and totally independent of ethnic or national processes and historical events. He does so because the range of the Carpathians has proven to be the most lasting state border in Europe. If this should be the case, we might safely assume that some sort of a natural (and not social) power prescribed this line of demarcation to function as a static state border (Figure 3). 


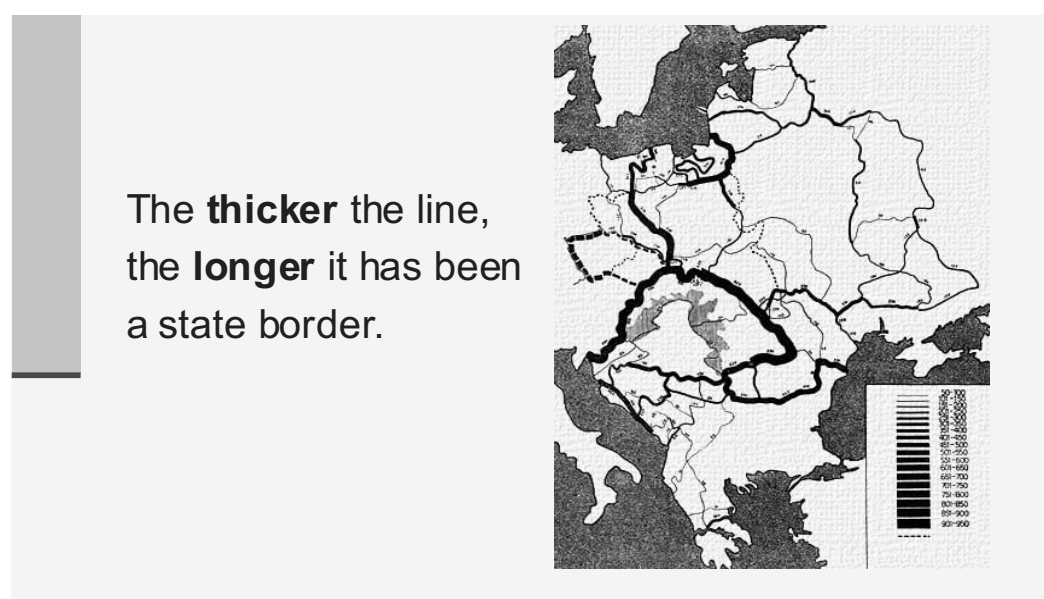

Figure 3. 'Time legitimizes the state borders'

These concepts reflect the inner system of relationships between the three issues of territory, nation, and national minority. To wit, nation states in the central and south-eastern parts of Europe attempt to express the cultural and linguistic fault lines separating the peoples living here in spatial terms as well. The roots of the notion of ethnic space are to be found in the fundamental characteristic feature of nascent nationalism in Central-Eastern and South-Eastern Europe: the effort to establish the maxim that state borders must correspond to ethnic borders. The reason for this is that those who live outside the legal framework of a given state but speak the same language and possess the same culture are also to be included in the "myth of common origin." The ideology of nationalism dawning in the process of the development of modern nation states gradually "discovered" the existence and the importance of "an ethnic space of one's own" after establishing national institutions and handling issues of language and culture. Therefore, the next step within the framework of nationalism was the mythologization and sacralization of this space.

The disciplines of statistics, cartography, and geography in the first half of the 20th century fulfilled expectations according to which geographers and cartographers should add the findings and achievements from their respective fields to the effort to prove the legitimacy of the notion of the leading role of the Hungarian nation in politics and culture in the Carpathian Basin. The arguments listed above represent the contemporary concepts of spatial studies that eventually combined into a unified network to serve a common goal. 


\section{References}

Veikko Anttonen (1999) Ihmisen ja maan rajat. "Pyhä" kulttuurisena kategoriana. Suomalaisen Kirjallisuuden Seuran toimituksia 646. Helsinki, Suomalaisen Kirjallisuuden Seura; Veikko Anttonen (1999) 'Nation and its Territory as Ritualized Space: Examining the Concept of the Sacred as a Boundary Marker in Finland' in Elek Bartha and Róbert Keményfi (eds) Ethnographica et Folkloristica Carpathica Tom. 11. Debrecen: Publications of the Department of Ethnography at the University of Debrecen, 9-22.

Alieda Assmann (2003) Erinnerungsräume. Formen und Wandlungen des kulturellen Gedächtnisses (München).

Hermann Bausinger (1965) 'Volksideologie und Volksforschung. Zur nationalsozialistischen Volkskunde', Zeitschrift für Volkskunde, Vol. 61, 177-204.

Umberto Eco (1976) A Theory of Semiotics (Bloomintgon).

Ernst H. Gombrich (1999) The Uses of Images. Studies in the Social Function of Art and Visual Communication (London: Phaidon).

Arthur Gribben (1990) 'Táin Bó Cuailnge: A Place On The Map, A Place on The Mind'. Western Folklore, Vol. 49 (July), 277-91.

[Imre Jakabffy] 1942. Rumänische Landkartenfälschungen und ihre Kritik (Budapest: Staatwissenschaftliche Institut).

Róbert Keményfi (2007) 'Karten machen - Macht der Farben. Zur frage der Visualisierung des ungarischennationalen Raumes', in Sabine Tzsaschel, Holger Wild and Sebastian Lent (Hrsg.): Visualisierung des Raumes. Karten machen - die Macht der Karten (Leipzig: Leibniz Institut für Länderkunde) 55-65.

Otto Neurath (1991) Gesammelte bildpädagogische Schriften. Band 3 (Wien).

Pierre Nora (1990) Zwischen Geschichte und Gedächtnis (Berlin).

Gyula Prinz (1942) Magyarország földrajza (Budapest: Renaissance Könyvkiadóvállalat).

Ute Schneider (2004) Macht der Karten (Darmstadt: Primus Verlag).

Edward W. Soja (1989) Postmodern Geographies. The Reassertion of Space in Critical Social Theory (London and New York).

Pál Teleki (1937) ‘Egy néprajzi térképről’, Földrajzi Közlemények, Vol. 65, 60-70.

Peter Watson (1985) Psycho-Krieg (Farnkfurt am Main: Econ).

Miklós Zeidler (2001) A revíziós gondolat (Budapest: Osiris Kiadó).

Miklós Zeidler (2002) A magyar irredenta kultusz a két világháború között (Budapest: Teleki László Alapítvány).

\section{Note}

1 See the Map: http://hu.wikipedia.org/wiki/F\%C3\%A1jl:Ethnographic_map_of_hungary_ 1910_by_teleki_carte_rouge.jpg 